\title{
Cutaneous Squamous Cell Carcinoma of the Head and Neck pT2 TNM Finding v8
}

National Cancer Institute

\section{Source}

National Cancer Institute. Cutaneous Squamous Cell Carcinoma of the Head and Neck pT2 TNM Finding v8. NCI Thesaurus. Code C133207.

Cutaneous squamous cell carcinoma of the head and neck with tumor $2 \mathrm{~cm}$ or larger, but smaller than $4 \mathrm{~cm}$ in greatest dimension. (from AJCC 8th Ed.) 